\title{
Henri Bremond and the Religious Experience in Context
}

\author{
Herman Westerink \\ Faculty of Philosophy, Theology and Religious Studies, Radboud University \\ P.O. Box 9103, 6500 HD Nijmegen, The Netherlands \\ h.westerink@ftr.ru.nl
}

\begin{abstract}
This article focuses on some psychological aspects of Henri Bremond's work, notably the development of a psychologie de la foi, the research into the sentiment réligieux and his reflections on the relation between what is traditionally called fides qua and fides quae. It is argued that in the center of the writings of Bremond, who is working in the context of the modernist movement and the rediscovery of the Catholic spiritual and mystical traditions in the modern era, one can detect a deep concern about the relation between religious (spiritual) experience and the official church teachings and institutions, and more specifically the relation between reflective thought and conscious reasoning on the one hand and 'implicit' spontaneous understanding and reasoning on the other hand. Also, in his writings one finds a fundamental discussion on the relation between mysticism and asceticism, and mysticism and poetry. Through the collection of material (mystics and their writings) and the elaboration of fundamental thematics, Bremond has become an important and also influential author. This article addresses this issue in particular in a short inquiry into the influence of Bremond on the work of Michel de Certeau.
\end{abstract}

\section{Keywords}

Bremond - psychology of religion - religious experience - spirituality - mysticism

As the title already indicates, this contribution is concerned with the writings of French literary scholar, philosopher, and theologian Henri Bremond (18651933) who became a member of the Jesuit order in 1892, but then left the order 
in 1904. He remained a priest until his suspension in 1909 for his presence and actions at the funeral of his friend and former fellow Jesuit, George Tyrrell. Bremond made the sign of the cross at Tyrell's funeral, even as he had been excommunicated in 1908 for his modernist standpoints regarding historicalcritical research, his plea for adjustment of dogmatic positions in view of scientific developments, and his criticism of papal authority. From these few lines we might already be able to define our context, namely the emergence of modernism in the Catholic Church, and its contestation. Indeed, the slim secondary literature on Bremond highlights his role in the modernist movement, his contacts with known modernists such as Tyrrell and Alfred Loisy, and in particular, the important part he played in the modernist turn to the mystical. ${ }^{1}$ In this contribution, however, I would like to focus on some psychological aspects of Bremond's work: the development of a psychologie de la foi (in the context of an emerging psychology of religion), the research into the sentiment réligieux and his reflections on the relation between what is traditionally called fides qua and fides quae, i.e., the relation between the mental act of believing and the doctrinal representations. I will therefore try to situate Bremond's turn to the mystical in a slightly different context, namely that of the emergence of psychological perspectives on religious life.

When Patrick Vandermeersch and I wrote a monograph on the psychology of religion in a cultural historical perspective more than ten years ago, ${ }^{2}$ we did not devote any attention to the sudden emergence of a body of literature on mysticism and spirituality around 1900 - a body of literature that for a substantial part was produced by Jesuit scholars amongst whom Henri Bremond was one of the most influential. This omission now appears puzzling to me. Of course, we can easily find an argument for not including this literature in a book on the emergence and history of the psychology of religion. After all, it will be hard, if not impossible, to find any handbook in the psychology of religion that would devote any attention to this literature in general or the writings of Bremond in particular. But then again, ten years ago we did not intend to write an ordinary handbook in this field. We explicitly chose for a cultural historical perspective in which the leading ideas were the following. The psychology of religion cannot be depicted as a consistent unity. It is not a scientific field

1 Guinan 1954; Goichot 2006; Talar 2003; id. 2007; id. 2009.

2 Vandermeersch/Westerink, 2007. 
composed of an autonomous scientific discipline - psychology - and a clearly defined object - religion. Quite to the contrary, psychology as one of the socalled human sciences emerged in the late nineteenth and early twentieth century from a variety of scientific and non-scientific disciplines, institutions, trends, and interests as an inconsistent amalgam of theories, methods and perspectives. One thing that was striking in the emergence of what eventually would be established in the universities as the field of psychology was the everpresent confrontation with religion. The fact that religion could become an object of scientific psychological interest resulted from a complex interplay of forces in which religion always was a key factor. It is impossible to understand the emergence of psychology in the nineteenth century without this strong interaction with religion.

This interaction could take many forms. One can think of the emergence of folk-psychology in the German context as a reflection on the German folk character that soon develops into a debate - first in philology and then later also in early psychology and comparative religious studies - on the differences between Aryan and Semitic folk-character as expressed in their myths and religious worldviews. ${ }^{3}$ One can think of post-Lamarckian or post-Darwinian evolutionist approaches to the mental development of peoples and cultures as expressed in different moral attitudes, different mentalities, and of course, different religious beliefs and practices that could now be systematized into a cultural developmental order starting from primitive animism or totemism and evolving into civilized monotheism, and from there into a scientificsecular worldview. Another important contextual element is that of the concurrently emerging field of psychiatry - a domain that claims emancipation from outdated religious worldviews on madness, but in fact in many ways continues pastoral techniques when it comes to the psychiatrist's authority and the moral treatment focusing on interventions into the patient's ideas and representations. It was notably in the context of debates in France on the relation between a new self-confident Catholicism on the one hand and the strong secular and anticlerical tendencies in society on the other hand that laicist psychiatrists and neurologists such as Jean-Martin Charcot would start studying past and contemporary demonic possession and other bizarre religious phenomena in relation to mental illness - sometimes with the explicit aim of discrediting religion while at the same legitimizing one's own discipline, institution, and practices. ${ }^{4}$ Yet another context concerns the problem of suggestion and manipulation - a problem that is related to suggestibility in religion,

3 Westerink 2008.

4 Westerink 2014. 
notably in overzealous preaching, mysticism, and extreme devotion as well as to a church that would often claim contribution to societal cohesion and moral and political consciousness. In the nineteenth century, with an interest for magnetism, hypnotism, occultism, and spiritism the underlying problems and questions are continued. How and to what effect can the emotional and mental life of individuals be manipulated? And is there perhaps a truth to be found in these extraordinary mental states - a supernatural revelation or a deeper unconscious truth of the individual, or both?

These are only some of the trends and discussions that develop throughout the nineteenth century and eventually come together in what will become scientific psychology - a psychology that will consider itself more and more emancipated from religion while making religion into an object of research and, as it were, repressing its more complex relation to religion. Having said this, I have not yet addressed the two decisive forces that contribute to the emergence of psychology in general and the psychology of religion in particular: philosophy and theology. As regards the philosophy, it is possible to identify some key issues and discussions without exploring every development in detail. The first problem concerns conceptions and study of the soul. The Cartesian model is certainly the most prominent one and it will dominate discussion on the relation between the physiological and the psychological and the separate or parallel study of these two. But the Aristotelian perspective on the soul also has its advocates. In Leuven, Cardinal Désiré Mercier establishes the Higher Institute of Philosophy in which empirical psychological inquiry into what Thomas Aquinas had named the intellectus agens, the autonomous and active processing of perceptions and sensations, had an important place as a promising alternative against scientific determinism which, as Evelyn Underhill later recalled, was in that time considered to be 'the chief enemy to a spiritual interpretation of life. ${ }^{5}$ Another key issue was the post-Kantian philosophical research into the working of perception, the acquisition of knowledge, and man's relation to reality. Was the latter based on a cooperation of the senses and reason, or was maybe the will and a fundamental belief in propositions more decisive? ${ }^{6}$ For the study of perception and sensations such as pain and pleasure, philosophical laboratories were established at various universities in Europe. ${ }^{7} \mathrm{~A}$ third key issue can be linked to an influence of Hegel in various directions. Firstly, there is a philosophical literature on the unconscious

5 Underhill 1990 [1929], p. xvi. On Neo-Scholastic psychology see, Kugelmann 2011, pp. 36-118.

6 William James argues for this second position in his The Will to Believe from 1896.

7 The first and one of the most important of these laboratories was Wilhelm Wundt's in Leipzig. 
emerging in the nineteenth century that expresses itself in dreams, religious representations and also delusions. Secondly and maybe more importantly, there is the emergence of empirical research into the growth of individual consciousness conceptualized in terms of a positive development through syntheses of inner conflicts. Notably in the late nineteenth century, this research is developed in the USA by protagonists of psychology such as Edwin Diller Starbuck and Stanley Hall and others - including William James. ${ }^{8}$ A central topic in this empirical research is the phenomenon of conversion and, related to this, religious experience (often with an implicit critique of dogmatic puritan religion).

This last topic brings us to theology. Against the background of ongoing secularization, critique of religion, and discussion on the relation between church and state or the role of religion in society, the nineteenth century witnesses a growing interest in religious experience and related topics such as religious moral attitude, religious needs, or religious value judgements relative to a discourse on 'the essence of religion'. As a starting point, we can identify Friedrich Schleiermacher's 1799 Reden über die Religion, an apologetic text against the so-called 'cultured despisers' of religion in which Schleiermacher argues that the enlightened and early Romantic critique of religion only touches on the secondary aspects of religion such as dogmas and institutions, in the process of which and unintentionally a new perspective on the vital essence of religion the religious feeling and intuition - is emerging. According to Schleiermacher, this religious feeling and intuition is closely related to aesthetic experience and in fact, it is at the heart of artistic - poetic - life. ${ }^{9}$ On the one hand this position will inspire a historical-critical analysis of the history of dogmas making room for a return to the - earliest Christian - lived faith. On the other hand, in the late nineteenth century, this position will be of great influence on an emerging discourse on religious experience, first in a Protestant theological context. Here, a psychological interest emerges, combining the critique of dogmatics and speculative theology with a strong plea for the primacy of reorganizing theology starting from the study of lived faith and religious experience. The re-publication of the Reden über die Religion in 1899 by Rudolph Otto was an important moment in this reception. Also, Wilhelm Dilthey's advancement of Schleiermacher's hermeneutics was important for a new theological engagement with psychological issues concerning the nature of affects and feelings involved in the process of interpretation and finding meaning. In this context,

8 An example is Starbuck's 1899 The Psychology of Religion: An Empirical Study of the Growth of the Religious Consciousness.

9 Schleiermacher 2006, second speech. 
important questions emerge. How can the affective and experiential core of religion be conceptualized without reducing it to human needs and projections? How can criteria be established for healthy and unhealthy religious life? How should the relation between individual lived religiosity and dogmatics or metaphysics be re-established, and what kind of religion will emerge from the modern turn to the experiences of the individual in an era of cultural Christianity? As regards the latter question, Ernst Troeltsch will focus attention on the mystic character of the modern and future religion that will evolve around individual experience of transcendence and a general humanism that is cultural and no longer ecclesiastically organized.

Although maybe from our current perspective, it sounds initially counterintuitive, we cannot be surprised that, given these developments in Protestant theology, that George Tyrell can write in 1898, in a letter to Henri Bremond, the following on this growing Protestant engagement with the lived subjective core of religion:

I am completely in agreement with you with regard to the coldness of modern Catholic piety as compared to a certain current among Protestants; but I imagine that it concerns a relatively recent trait in both; a reaction of the latter against the aridity of the rationalist spirit which is the soul of Protestantism, while Catholics, in opposition to the 'fluency of the word', to the indeterminate character, the sentimentalism of Protestants, have insisted on definitions and reason to an extreme that has killed mysticism for the time being. ${ }^{10}$

But can Catholic theologians simply follow in the footsteps of Protestant predecessors? Or should they develop their own psychological approach to religious life and define its relations to tradition, systematic thought, church authority, and so on? Are there trends in the emerging psychology they can connect to or disengage from? And are there models and paradigms to be found in the tradition, and if so, which ones?

\section{Bremond's Search for Paradigms}

The need for a Catholic psychology of religion was felt to be a pressing matter around 1900, notably in France. From the mid-nineteenth century onwards, leading French psychiatrists such as Maurice Macario, Alexandre Brierre de

$10 \quad$ Cited in Talar 2009, p. 13. 
Boismont and notably Louis-Florentin Calmeil started to study past and contemporary extreme religious phenomena in relation to mental illness. One could say that this trend was a reaction against the Restoration in France, in which the church regained societal influence, manifesting itself in a selfconfident manner in the public sphere, as evidenced in the sudden rise of Marian apparitions, demonic possessions, miraculous cures, spectacular stigmatisations and visionaries, not only in France but also in other European countries. Some psychiatrists clearly represented an anticlerical perspective on religion, arguing that religion inherently leads to pathological formations. Others were interested in psychiatry's contributions to the conceptualization of true (normal) and pathological religiousness, while putting to the fore the societal necessity and utility of religion as a foundation for civil morality. These French psychiatrists - whatever their motives and intentions - had a common interest that French neurologists would soon claim to be their territory par excellance: the hysteric convulsions that, as Certeau and Foucault have shown, were a phenomenon deeply rooted in the French spiritual tradition - one can think of the collective possession at Loudun and the later the convulsionists of St. Médard. ${ }^{11}$

The Paris neurologists and known laicist republicans Désiré-Magloire Bourneville and Jean-Martin Charcot were fascinated by the hysteric symptom formations apparent in the lives of the stigmatized, demon-possessed, ecstatics and mystics. For these neurologists, the historical data pointed in only one direction: most excessive forms of religiosity could be reinterpreted in terms of hysteria and should therefore be considered pathological. ${ }^{12}$ It was thus in the second half of the nineteenth century that first psychiatrists and then also neurologists sought to reinterpret certain religious phenomena in terms of mental illness, not the least with the aim of legitimating their own institutionalized medical discipline, research, practices and nosological categories. This had strong impact on a next generation of scholars such as Pierre Janet with his studies on hysteria and dissociation and Sigmund Freud with his study of religion from the perspective of the psychopathologies. On a more fundamental level, by focusing on extreme forms of individual religious behaviour, psychiatry and neurology determined a much broader agenda than those of individual scholars when raising fundamental questions such as 'How are certain forms of religiosity related to suggestion and manipulation?', and 'With what criteria can a distinction be made between normal (healthy) and pathological religiosity?'

\footnotetext{
11 Certeau 2000; Foucault 2003.

12 Céard, 1994; Lachapelle, 2011. See also, Westerink 2014.
} 
Unlike contemporaries, such as the philosopher and psychologist of religion Henri Delacroix and his 1908 study of healthy and pathological forms of mysticism, ${ }^{13}$ Henri Bremond does not directly and explicitly respond to the problems and questions Charcot cum suis had been interested in. Bremond's interest is clearly a psychological one, but does not concern the question of normal versus pathological mysticism. In his earliest works on Cardinal John Henry Newman, from 1904 to 1906 , he makes clear that the 'object' of his research is the Cardinal's inner life while 'relegating his doctrine to a sort of appendix' - a doctrine he regards merely the expression or manifestation of what is essential, the individual religious experiences. ${ }^{14}$ One might ask, why Newman? According to Bremond, Newman's place in religious history is that of a pioneer

who accelerates, and also moderates, the irresistible current which sweeps onward contemporary thought. In putting conscience, Christian experience, and personal realisation of the Divine, at the base of the whole religious structure, he collaborates without knowing it in the work of Schleiermacher and his disciples. ${ }^{15}$

Bremond's answer to the pressing question of a Catholic psychology of religion consists in this connection to a Protestant tradition of a primacy of religious experience. For Bremond, Newman is a sceptical-poetical-humanistic and controversial author - not the least because of his subsequent conversions to Calvinism, Anglicanism and then Catholicism - that par excellance in his writings he 'discloses himself and tells his own story'. His work is a strongly 'autocentric' product of self-contemplation having 'I' and 'me' written in every sentence. But not only does Newman connect to Schleiermacher's legacy, Bremond also remarks that Newman can be situated in a seventeenthcentury body of literature that is focused on the essence of doctrine and religious institutions, i.e. the doctrine de la foi, the 'modern' philosophical and religious reflection on grace, prayer, pure faith and pur amour. ${ }^{16}$ In his reading of Newman's works, Bremond is particularly interested in the personal motives

13 Delacroix 1908; Pizarroso 2014. Henri Delacroix was a colleague and friend of Henri Bergson and Marcel Mauss. His interest in mysticism was strongly influenced by the earliest American psychology of religion (Leuba, James). In his 1908 study on mysticism, he argues that pathological aspects in mysticism are often found in minor mystics, but seldom in grand mystics such as Theresa of Avila and Mme Guyon.

14 Bremond 1904, 1905, 1906 (the latter translated as The Mystery of Newman, 1907).

15 Bremond 1907, p. 332.

16 Bremond 1905, p. 10. 
and experiences that underlie what Newman himself named his 'unconditional' adhesion to Catholic doctrine. What conditions this 'unconditional'? It is this question that leads beyond the content of doctrine towards "what Bremond describes as 'disinterested' and 'isolated' private" inner relation with the divine, that is, on the one hand, "the conviction that God has spoken and that He has taken possession of the soul for ever", but is on the other hand the distrust of self, the hesitations and feelings of timidity when realizing the silence and hiddenness of God, the indirect and distant presence that makes the man melancholic and which makes him cling to doctrine. ${ }^{17}$ Pathos about presence and melancholic dryness about absence characterize the inner religious life of Newman, and for this very reason, his is a paradigmatic experience for modern mysticism, says Bremond.

For Bremond, Newman was a key figure to understand both religious past and present. Bremond highlights Newman in order to develop his ideas on the relation between rationality and irrationality. ${ }^{18}$ In the context of a growing critique on positivist, materialist and naturalistic approaches in science notably in the French neurology and related fields, the question of the status of rationality in religion and theology had become a prominent issue. How to review the role of rational argumentation and knowledge by heart in faith? In other words, is faith irrational, and if so, what does one mean by faith and irrational? Bremond does not find the sharp distinction between rationality and irrationality in faith very fruitful. To the contrary, referencing Newman, he argues that what is often named irrational should in fact be thought of as 'implicit thought' - a spontaneous understanding and reasoning distinct from reflexive and fully conscious reasoning. The contemporary relevance of Newman was thus seen in him developing an alternative for a rationalist, intellectualist theology - in the background we recognize the critique of Neo-scholastic thought and the modernist's interest in encultured religious life. Newman provides the material to point at the layered structure of religious commitment: underneath dogmatic reasoning, objectifying ratio, and adhesion to church authority, we find the more fundamental 'irrational' lived experiences of faith, the psychological 'subjective' disposition (desire, pathos, receptivity, conscience, etc.) relative to the personal history of the individual that needs further study. This is the direction Bremond's psychology of religion will take.

In 1901, Bremond had already communicated to Friedrich von Hügel, an Austrian modernist religious writer who would soon become well-known for a study on Catherine of Genoa, The Mystical Element in Religion (1908)

17 Bremond 1907, p. 267-281.

18 See, Talar 2003. 
and for promoting the writings of Troeltsch, that he wanted to write an extensive history of religious experience - sentiment religieux - in nineteenthcentury England ${ }^{19}$ - a project that would not be realized but in which certainly Newman would play a leading role. Indeed, the idea of a history of the religious experience soon took a different turn. Bremond, having discovered the fundamental connection between aspects of Newman's religious inner life and seventeenth-century mysticism and devotion, now turned attention to the seventeenth-century, focussing indeed on the sentiment religieux, the mystic's inner life, but also other central aspects that had shaped Newman's religious life and theology, i.e. the relation between the fundamental religious experiences with rationalized doctrine and adhesion to institutions. The work of Newman thus is a key to understand Bremond's turn to early modern religious experience, notably also to grand debates in the seventeenth century in which the nature of faith and the relation between faith and reason were at stake.

More concretely, Bremond turns attention to a crucial debate in the seventeenth-century, a debate that effected the vicissitudes of mysticism for centuries, in fact until its rediscovery by Charcot cum suis: the debate between the two rivalling bishops Jacques-Bénigne Bossuet - the hero of Catholic traditionalists and conservatives who regarded mystics an even greater danger for the Catholic church than Protestants - and Francois Fénelon, the defender of Mme Guyon's ideas on prayer. On this debate, Bremond publishes Apologie pour Fénelon in 1910 - a text about a misunderstood religious genius not coincidentally published the year after George Tyrrell's death. This text, in which Fénelon is not portrayed as an ambitious political actor, but as a person deeply concerned with inner life and religious experience, also in many ways preluded what would become Bremond's magnum opus Histoire littéraire du sentiment religieux en France depuis la fin des guerres de religion jusqu'à nos jours, published in 11 volumes between 1916 and 1936.

With the turn from Newman to Fénelon and the seventeenth century, the elaborations of religious experience and inner life took the form of explorations of modern mysticism. Bremond was not the first to turn attention to what one might call psychological perspectives on mysticism. In France, Delacroix, but also others such as the Jesuit Augustin Poulain (Des Grâces d'oraison. Traité de théologie mystique, 1901) and Auguste Saudreau (L'État mystique, 1908)

19 Talar 2007, p. 179. 
held similar inquiries. Other important publications such as Von Hügel's The Mystical Element in Religion and Evelyn Underhill's Mysticism (1911) were soon to follow. This literature raised new fundamental question, notably on the nature, causes and effects of mysticism, as well as its relation to general spiritual life and moral behaviour.

As regards different views on the nature of mysticism, it was Poulain who formulated a first position that was in a sense traditional as it connected with the tradition of Bossuet: the extraordinary experiences that define mysticism are exceptional and will only be found in a small group of people that 'feel' and 'realize' the presence of divine grace; this 'feeling' is not so much an emotion, but in fact an 'experimental, intellectual knowledge' infused by God. Saudreau on the other hand claimed that the experience of divine presence is not essential to or an exclusive aspect of mysticism. Mysticism instead can better be defined in terms of 'knowledge and love of God'. ${ }^{20}$ Bremond would soon define his own position between Poulain and Saudreau, arguing that Poulain's view was too intellectualistic, whereas Saudreau had denied the direct knowledge and felt presence of God. According to Bremond, Saudreau however, had rightfully argued for continuity between ordinary devotion (such as prayer) and mysticism - both phenomena displaying detachment from the self and exercising pure love. In other words, mysticism was not exceptional, but a normal aspect of spiritual life - it is also not sharply distinguished from asceticism. It is the infusion of an immediate consciousness and knowledge of God that has to be distinguished from doctrinal knowledge as acquired through teaching in the background; we hear an echo of Schleiermacher's views on the immediate feeling and intuition of transcendence.

In the context of this article, it is impossible to present a thorough analysis of the Histoire littéraire du sentiment religieux. I will only present a few major aspects and characteristics of the work. First, Bremond is only interested in the modern era, notably the seventeenth century as an age which witnesses the rise and fall of a strong mystic current in French Catholicism - the period roughly between Francis of Sales and Fénelon. He is interested in the causes, the essence and characteristics of the mystical current, but also in its influence on moral, literary, social, and political life. Formulated in different terms, Bremond's undertaking is a study in the religious life that has a layered structure, its essence being inner life and its 'surface' being social, moral and

20 See, Talar, 2007, 2009. Compare also Bremond 1927 (Prayer and Poetry), chapter 13 and Bremond 1930a, pp. 431-446. In the appendix to the second volume of Histoire littéraire du sentiment religieux Bremond explicitly discusses the positions of Poulain and Saudreau, and others, notably J.R. Maréchal and R.P.L. de Grandmaison. 
political. Second, although Bremond limits himself to the Catholic sentiment réligieux, his general approach is not confessional. In the introduction to the first volume, he writes that in order to have a complete picture he would have needed to include Protestant and Anglican mysticism as familiar and crossinfluential. What is explicitly excluded by Bremond is Jansenism, which for him represents the kind of rationalistic, intellectualist movement that stands in opposition to the history of religious experience. ${ }^{21}$ Third - and here we see him allying with Saudreau -, Bremond chooses not to focus solely on grand writers such as Sales and Fénelon but on a much broader devotional literature that shares the same thing, namely that they are 'lived' writings, that is, that life-stories are written in them - compared with what we have said about Bremond's studies of Newman. "The world and the cloister touched and penetrated each other, so to speak, on all sides", Bremond concludes, and the seventeenth-century "charms of devotion breathed their subtle fragrance into every heart" and every cultural domain. ${ }^{22}$ This stream of devotion can also be named 'mystical' - mystical not as pointing at extraordinary 'experience' but at 'life', that is, moreover, inner-life and its manifestations in 'humanist' religious, moral, political and literary life. Fourth, as regards mysticism, Bremond describes this phenomenon as "that natural disposition which leads certain souls by a sort of sudden compulsion to seize with direct and daring love on the spiritual beneath the veil of sense, the one in the many, the order amid the confusion, the eternal in the transitory, the divine in the created" resulting in new interior knowledge, an 'impression of understanding something more of the unknown' and 'union with an object beyond the frontiers of the tangible..23 This 'mystic state' as "the consciousness of the immediate Presence of a transcendent Being"24 is in principle something every human being is capable of in fact, the desire for this inner union is not even specifically Christian, but much more a general trait of early modern humanism. Given the fact that this mysticism is part of a broader early modern humanism and 'embedded in a living milieu' of spiritual renaissance, this modern mysticism is of another nature than medieval mysticism - a mysticism that Bremond hardly refers to and is completely uninterested in.

\footnotetext{
21 Bremond 1928, pp. xi-xxiii.

22 Bremond 1928, p. xvii.

23 Bremond 1928, p. 400 et seq.

24 Bremond 1930a, p. $43^{2}$.
} 
In the Histoire Bremond states that his magnum opus does not aim at a psychological theory of mysticism, i.e., mystical experience. ${ }^{25}$ That does not mean that Bremond does not engage with such a theory in his work. In a preface written in 1930 to one of the later editions of Mysticism, Evelyn Underhill praises Bremond not only for his historical research and for disclosing a large collection of mystical literature, but also for his 'religious psychology' that is based on "the acknowledgement of a genuine two-foldness in human nature - the difference in kind between Animus, the surface-self, and Anima, the transcendental self, in touch with supernatural realities." According to her, this theory opens up new ways for understanding contemplation and mystical experience as "an activity of the transcendental self" operating notably in religious, poetic and aesthetic apprehensions while not being guided by rational thought. ${ }^{26}$ For Underhill, this theory is valuable as it supports her own ideas on the 'mystic way' as a developmental inward process of growing consciousness of living union with the One. This developmental approach stands in opposition notably to William James' views of mystical experiences as passive immediate experiences of the divine infusing a person with 'hypotheses' on the divine that are then further developed into philosophical and theological reflexive thought as an object of exploration. For Underhill, the experience is already resulting from psychic activity that not only results in the union with the divine, but also in a practical way of life inspired by love of the divine. Again, we are confronted with a fundamental debate on the nature and characteristics of mystical experience - a fundamental debate in which Bremond is also involved. Despite the differences between protagonists such as Underhill and James, we should not overlook the similarities, notably the idea that, for both, mystical experience is the core of religion. ${ }^{27}$

Bremond's late psychological theory of mystical experience connects to his earliest intuitions from the Newman works: the distinction between reflective thought and conscious reasoning on the one hand and 'implicit' spontaneous understanding and reasoning on the other. He develops his ideas in his 1925 Prière et poésie (dedicated to his friend and ally Maurice Blondel) and the 1929 Introduction à la philosophie de la prière. Again, there is the close connection between poetic (aesthetic) and mystical (religious) experience - a connection that notably becomes visible in the Romantic era in which the profane

25 Bremond 1930a, p. xxi.

26 Underhill 1990, p. xvi. Compare also the footnote on p. 53 et seq.

27 Bridgers 2012. 
poetic experiences come close to mystical states of the soul - again, an echo of Schleiermacher's views. In fact, Bremond claims, the poetic experience can best be understood through a psychological analysis from the perspective of the mystical experience. ${ }^{28}$ But also other phenomena, like patriotism, in which the 'idea' of a country becomes a 'living being' that penetrates and possesses the heart of a person - a process Newman had called 'realization' of divine presence - can be understood from psychological insight in mystical experience. ${ }^{29}$

Already from the first sentences of the introduction, we can understand what attracted Underhill in Bremond: "In the course of the normal development of man, there occur moments in which the discursive reason gives place to a higher activity." ${ }^{30}$ At the heart of Bremond's psychological theory, there is indeed this distinction, which he associates with the concepts of animus and anima. This is not to be understood as a reference to the work of Carl Gustav Jung, as one might be tempted to think; the concepts are derived from the work of the author and poet Paul Claudel. Animus denotes the surface self, rational knowledge, the 'I', the poor ego "who dances around the circumference of the soul" absorbed in the contemplation of objects but also engaged in bourgeois societal life. Anima denotes the deep self, mystical and poetical knowledge. It is 'Me' united with reality, receiving visits from God, the soul listening to the 'symphonies of silence'. ${ }^{31}$ Bremond associates this distinction with known distinctions from mystical and poetic literature such as the distinction between amour proper and amour pur, or spirit and soul.

Bremond not only underscores this distinction, but also the necessary collaboration between I and Me, animus and anima, that is to say, the inevitable effect of mystical experience on intellectual and affective life. ${ }^{32}$ Bremond is describing this effect in terms of a religious, moral and intellectual life lived from the conviction that "God is always there, but he does not make himself any longer felt", in other words, a life lived in the loving memory of a felt presence, the "indefinable half-remembrance of a past experience". ${ }^{33}$ Bremond stresses this aspect of memory of an experience that strictly speaking was merely an

28 Bremond 1927 , p. 84. Bremond notes that he is not the first to point at the deep connection between the poetic and the mystical experiences. He does not refer to Schleiermacher, but amongst others to Alfred Sharpe's 1910 Mysticism, its True Nature and Value, and the already mentioned theories of Maréchal and De Grandmaison.

Bremond 1927, p. 94.

Bremond 1927, p. 1.

Bremond 1927, p. 109.

Bremond 1927, p. 145-150.

33 Bremond 1927, p. 151 . 
intuition of being absorbed in the divine, an absorption that sets in motion a whole range of inner movements - will, desire, passion, fear, agitation - that strictly speaking are already responses to the experience, responses that will find direction and orientation in the subsequent mystical life that feeds on the memory of the experience.

\section{$5 \quad$ Michel de Certeau's Perspective on Bremond}

The psychological approach that Bremond already first develops in his studies on Newman and later more explicitly elaborates in various writings, notably his texts on prayer and poetry, is hardly systematically reviewed in literature. One of the few scholars reflecting this approach is Michel de Certeau - a Jesuit historian, philosopher an theologian who, in his own way, stands in the tradition of the 'study of spirituality and mysticism' as developed by Bremond and others, and who in contemporary scholarship is considered to be one of the major theoreticians in this field. For Certeau, Bremond is a collector of 'souls' who, while collecting in a sense, also lets these souls 'slip away'. In his 1973 and 1975 writings on history, ${ }^{34}$ he underscores the loss of confidence in doctrine, institutions and reflexive reasoning in Bremond's reference to a 'mystical' depth, an essence in man and religion (and poetry) that is repressed from and compromised in doctrine. A 'slippage' from this hidden depth is foreign to social and intellectual categories; it escapes reflexive thought and objectifying conceptualization. Beyond the historical surface, one finds a 'metaphysics', that is the felt intuitive knowledge of the divine, the immediate, but also in a sense 'unconscious' contact between 'Me' and God that can merely be traced in the saintly lives and throughout history - the memory traces, so to speak, in writings, autobiographical accounts, activities, influences, et cetera. Certeau associates this 'slippage' with the fundamental crisis in modernity, the loss of presence of the divine that is so clearly manifest in the modern mystic's melancholic desire for a past presence. According to Certeau, Bremond had recognized this as early as his writings on Newman and later made this the central idea in his psychology of mysticism: the relation between experience (of presence and absence), memory, and melancholic desire. Certeau thus highlights in Bremond an aspect of his own thought, namely the distinction between the mystic experience and the mystic discourse as interpretations and (re)-constructions of the experience ... if there was any. Certeau thus connects to some central aspects of Bremond's psychological theories, but without 
embracing the strong essentialism and ontological claims concerning the distinction between animus and anima, or surface self and deep self. In Certeau's thought, there is no place for a deep self. There is only an 'I' that desires.

The significance of the presence of Bremond in Certeau's writings should not escape our attention. Without wanting to use the concept of identification, there clearly is a certain consciousness of continuity in Certeau's texts. After all, was not the Jesuit Certeau asked to write a history of the Jesuit order that eventually developed into writings on modern mysticism relative to the emergence of the modern subject and the interiorization of faith? And in doing so, was Certeau not always already stepping in the footsteps of that 'collector of souls' that would establish a corpus of modern mysticism? And was not Certeau interested in the same kind of questions, i.e. the nature of mystic experience, the emergence of mystic discourse, the effects on ways of life and the conflict-laden relation with established doctrine and institutions? Without answering these questions directly, what seems particularly interesting here is the fact that Certeau, already in the 196os, in his earlier explorations of the history of the Jesuits, shows a keen interest in the mystic tradition in that history - a tradition that points towards fundamental debates on mysticism in that history, notably in the sixteenth and seventeenth century, and in the twentieth century. It is Bremond amongst others who takes position in this debate. For Bremond, the struggle or conflict within the Jesuit tradition can best be translated in terms of mysticism against asceticism. Bremond sharply distinguishes between the two. Mysticism is passive, being grasped by the divine. Asceticism is a self-affirming activity and agitation of the soul - will, understanding, commemoration - put into a 'calculated system' and 'machinery' of practices and exercises. In the third volume of the Histoire (1921), Bremond suggests that Ignatius' Exercises can be seen as ascetic, i.e. characterized by laborious and heroic energy and struggle. ${ }^{35}$

Nevertheless, in the late 1920s, Bremond draws another conclusion from looking at the Exercises from the perspective of Ignatius' autobiographical works: central is the contemplation and experience of the love of God, and for this reason, Ignatius' work should be named mystical. For Bremond, this mystic core of Ignatian spirituality is continued in the seventeenth century by figures such as Louis Lallement and Joseph Surin. The larger part of the Societas, however, became the ascetic militant practico-political order that essentially not only misunderstood but also betrayed Ignatian mysticism. In the eighth volume of the Histoire (1930) Bremond goes so far as to describe asceticism as anti-mystical and a reaction against mysticism - hence, in a way 
an ally of rationalist tendencies. ${ }^{36}$ This anti-mysticism is however not primarily motivated by intellectual thought, but much more by an irrational fear of uncontrolled - and hence, unorthodox (undogmatic) - subjective mystic ways of life, and a fear of loss of authority among the religious-political elite.

Bremond is an important voice in twentieth century Jesuit thought on this topic of Jesuit mysticism. Certeau is fascinated by this tradition, as evidenced in his engagement with Joseph Surin - the seventeenth-century Jesuit mystic who occupies a central place in Certeau's work from the 196os onwards. Again, this article is not the place for a detailed analysis of the relation between Bremond's and Certeau's ideas on Jesuit mysticism. The important theoretical point, however, should not escape our attention, namely the debate on the relation between mysticism and asceticism. Are they opposed or collaborative forces in the history of spirituality? Is asceticism the modern reaction against modern mysticism? Can the difference between asceticism and mysticism be articulated in psychological terms - as Bremond suggests when opposing psychic passivity to activity? Or is mysticism perhaps itself an activity, a practice as Certeau suggests when he reasons that the experience of presence is always already lost, and the mystic being the person who is fully absorbed in the practice of 'making present'?37 In this perspective, the difference between mysticism and asceticism becomes less relevant, as the focus shifts towards the force and energy (desire) to make the divine present in a way of life that does not coincide with acquired habits and adhesion to doctrine.

\section{Biography}

Herman Westerink is Senior Researcher at the Titus Brandsma Institute, Associate Professor at the Center for Contemporary European Philosophy, Radboud University Nijmegen, and Extraordinary Professor at the KU Leuven. He has published numerous books and articles in psychology of religion, philosophy of religion, and philosophical anthropology and psychoanalysis, amongst others Reformation(en) und Moderne. Philosophisch-theologische Erkundungen (2017) with Hans Schelkshorn (editors), and recently Modernity, Melancholy and Predestination. Cultural historical, philosophical and psychoanalytical perspectives on the modern religious subject (2019).

\footnotetext{
36 Bremond 193ob, fourth part (notably pp. 181-183, 223-227). On this issue see Salin 2002; Trémolières 2017.

37 Certeau 1992.
} 


\section{Bibliography}

Bremond, Henri: Newman. Le développement du dogme chrétien. Paris: Librairie Bloud 1904.

Bremond, Henri: Newman. Psychologie de la foi. Paris: Librairie Bloud 1905.

Bremond, Henri: Newman. La vie chrétien. Paris: Librairie Bloud 1906 (translation: The Mystery of Newman, London: Williams \& Norgate 1907).

Bremond, Henri: Histoire littéraire du sentiment religieux en France depuis la fin des guerres de religion jusqu'à nos jours, Tome I-III. Paris: Bloud et Gay 1916-1921 (translation: A Literary History of Religious Thought in France, Vol. I-III. London: Society for Promoting Christian Knowledge 1928, 1930a and 1936).

Bremond, Henri: Histoire littéraire du sentiment religieux en France depuis la fin des guerres de religion jusqu'à nos jours, Tome viII. Paris: Bloud et Gay 1930 b.

Bremond, Henri: Prière et poésie. Paris: Bernard Grasset 1926 (translation: Prayer and Poetry: A Contribution to Poetical Theory. London: Burns Oates \& Washbourne 1927).

Bridgers, Lynn: "The Head and the Heart: William James and Evelyn Underhill on Mysticism", in: William James Studies 9 (2012), pp. 27-36.

Céard, Jean: "Démonologie et Démonopathies au temps de Charcot", in: Histoire des sciences médicales 4 (1994), pp. 337-343.

Certeau, Michel de: "Henri Bremond, historien d'une absence", in: L'absent de l'histoire. Paris: Mame 1973, pp. 73-108.

Certeau, Michel de: The Writing of History. New York: Columbia University Press, 1988 (originally published in 1975 as L'écriture de l'histoire).

Certeau, Michel de: The Mystic Fable. Volume I:The Sixteenth and Seventeenth Centuries. Chicago: Chicago University Press 1992 (originally published in French in 1982).

Certeau, Michel de: The Possession at Loudun. Chicago: Chicago University Press, 2000 (originally published in 1970 as La possession de Loudun).

Delacroix, Henri: Études d'histoire et de psychologie du mysticisme: les grands mystiques chrétiens. Paris: Félix Alcan 1908.

Foucault, Michel: Abnormal. Lectures at the Collège de France 1974-1975. New York: Picador 2003.

Goichot, Émile: Henri Bremond, Historien de la "Faim de Dieu", F. Trémolières (ed.). Grenoble: Éditions J. Millon 2006.

Guinan, Alastair: "Portrait of a Devout Humanist: M. l'Abbé Henri Brémond. An Essay Introductory to his Life and Thought", in: The Harvard Theological Review 47 (1954), pp. $15-43$.

James, William: The Will to Believe. New York: Longmans, Green \& Co. 1896.

Kugelmann, Robert: Psychology and Catholicism. Contested Boundaries. Cambridge: Cambridge University Press 2011. 
Lachapelle, Sofie: Investigating the Supernatural: From Spiritism and Occultism to Psychical Research and Metaphysics. Baltimore: John Hopkins University Press 2011.

Pizarroso, Noemi: "Henri Delacroix's Psychology of Religion in Context: Between Secular Religious Sciences, William James' Psychology and Marcel Mauss' Sociology", in: International Psychology, Practice and Research 5 (2014), pp. 1-32.

Salin, Dominique: "Methods for Sancho Panza: Henri Bremond and the Interpretation of the Ignatian Exercises", in: The Way Supplement 103 (2002), pp. 66-67.

Schleiermacher, Friedrich: On Religion. Speeches to its Cultural Despisers. Cambridge: Cambridge University Press 2006.

Sharpe, Alfred: Mysticism, its True Nature and Value. London: Sands 1910.

Starbuck, Edwin Diller: The Psychology of Religion: An Empirical Study of the Growth of the Religious Consciousness. London: W. Scott 1899.

Talar, Charles: “Assenting to Newman: Henri Bremond's 'Psychologie de la foi", in: The Downside Review 121 (10/2003), pp. 251-270.

Talar, Charles: "The Historian and the Mystic: The Revisionist Vision of Henri Bremond", in: The Downside Review 125 (7/2007), pp. 177-196.

Talar, Charles (ed.): Modernists and Mystics. Washington: The Catholic University of America Press 2009 .

Trémolières, Francois: “The Witness to these Witnesses': Henri Bremond", in: Maryks, R.A. (ed.): A Companion to Jesuit Mysticism. Leiden: Brill 2017, pp. 253-278.

Underhill, Evelyn: Mysticism. The Preeminent Study in the Nature and Development of Spiritual Consciousness. New York: Doubleday, 1990 (originally published in 1910).

Vandermeersch, Patrick/Westerink, Herman: Godsdienstpsychologie in cultuurhistorisch perspectief. Amsterdam: Boom 2007.

Westerink, Herman: "Zum Verhältnis von Psychoanalyse und Mythologie. Die Einflu $\beta$ Heymann Steinthals Völkerpsychologie auf die angewandte Psychoanalyse", in: Psyche. Zeitschrift für Psychoanalyse und ihre Anwendungen 62 (3/2008), pp. 290-311.

Westerink, Herman: "Demonical Possession and the Historical Construction of Melancholy and Hysteria”, in: History of Psychiatry 25 (3/2014), pp. 335-349. 